\title{
The Influence of Audit Committee Characteristics on Modified Audit Opinion in Jordan
}

\author{
Saleh Zaid Alkilani', Wan Nordin Wan Hussin ${ }^{1}$, Basariah Salim ${ }^{2}$ \\ ${ }^{1}$ Othman Yeop Abdullah Graduate School of Business, Universiti Utara Malaysia, Sintok, Malaysia \\ ${ }^{2}$ Tunku Intan Shafinaz Accounting School, Universiti Utara Malaysia, Sintok, Malaysia
}

Email address:

salehalkelani17@gmail.com (S. Z. Alkilani),wannordin@uum.edu.my (W. N. W. Hussin),

basa1189@uum.edu.my (B. Salim)

\section{To cite this article:}

Saleh Zaid Alkilani, Wan Nordin Wan Hussin, Basariah Salim. The Influence of Audit Committee Characteristics on Modified Audit Opinion in Jordan. Journal of Finance and Accounting. Vol. 7, No. 3, 2019, pp. 95-106. doi: 10.11648/j.jfa.20190703.14

Received: April 27, 2019; Accepted: June 11, 2019; Published: July 4, 2019

\begin{abstract}
The Jordanian Corporate Governance Code (JCGC) was first enacted in 2004 and revised in 2017. It offers standards for ethical and decent practices in the corporates. Law in Jordan in 2009 has enforced the formation of an audit committee for all listed companies. Literature has substantiated that the audit committee characteristic (ACCs) impact the quality of financial reporting. This work investigates the role of ACCs in lessening the prospect of corporates in obtaining modified audit opinion in the context of Jordan. Four ACC problems (expertise, independent, meeting, and size) have been studied and the modified audit opinion. The total sample of 117 listed companies on the Amman Stock Exchange (ASE) was studied. The relationship between the modified audit opinions (dependent variable), and ACCs (expertise, independent, meeting, and size; as independent variables) was analyzed using logistic regression. The ACCs is projected to effectively improve the quality of financial reporting, and thus, decrease the prospect of corporate in obtaining modified audit opinion. The findings according to the listed companies from 2012 to 2017 in Jordan showed that audit committee (AC) expertise validates this likelihood. Lastly, there is no effect of AC independent, size, and the number of meetings held on the modified audit opinion. General, the findings have policy implications on enhancing corporate governance (CG) efficacy concerning the quality of financial reporting.
\end{abstract}

Keywords: Audit Committee, Corporate Governance Guide, Modified Audit Opinion, Type of Auditor's Report

\section{Introduction}

Following the disastrous and tragic impact of corporate scandals and crises that result in failure of giant firms, for example, Enron, WorldCom, etc. had a shocking influence on the quality of financial reports [1-3]. Many groups have called for the enhancement of CG practices. In line with this, there are four significant $\mathrm{CG}$ mechanisms e.g. AC, boards of directors (BoDs), internal and external audit roles that are directly involved in this matter [4]. The AC, management, and external auditor have distinctive functions in financial reporting. For instance, the BoDs has a critical function in guaranteeing the quality of financial statements of firms' practices [5]. This is because the management is in charge of formulating the financial reports $[6,7]$, creating and sustaining sufficient internal control above the financial reporting [8]. Hence, the AC's key responsibility is monitoring the process of financial reporting to safeguard ethical and decent financial statement by the managers on firm performance. This is along with supervising the efficiency of internal controls, and activities of external auditors [9]. It boosts the BoDs (principals) capability to act as a management supervisor by offering more comprehensive knowledge and insight for financial reporting [10].

The external audit functions act as a supervising instrument to safeguard the quality of financial information. Hence, the external auditor is taken as a fundamental aspect of the CG structure $[11,12]$. Further, the external auditors are deemed as overseers, because they build a repute only by offering an independent authentication of the financial reports organized by company management. Whereas the external independent auditor is liable for expressing opinions on the fairground based on what financial reports show. Also, in line with all measurable terms in compliance with 
Accounting Principles Generally Accepted [GAAP; 13]. Consequently, when the $\mathrm{AC}$ is characterized by expediting the labor of the external auditor, then the auditor's opinion regarding the financial reports should be enriched [14]. This should be developed from a qualified opinion to a positive one, or generate certain reforms to the qualities and recommendations [15]. Thus, the AC must work with management and the external independent auditor to obtain the knowledge needed to deliver appropriate supervision of the process of financial reporting. Moreover, the $\mathrm{AC}$ is responsible for supervising the whole process of financial reporting $[4,16,17]$. In order to successfully achieve this, the AC must familiarize with the practices and controls that management has instituted to ascertain whether they were planned efficiently.

The AC is regarded as one of the components in-charge of monitoring the shareholders' interests and financial reports [18]. This may be due to the fact the main task of the AC is monitoring the practice of financial statements and control. In order to safeguard the veracity of its practices of financial reporting and the auditing process [19]. Literature has indicated that ACCs impacts the quality of financial reporting $[20,16,21,7,22,23]$. Consistent with Salehi \& Shirazi, [21] and Bajra \& Čadež, [7] who revealed that ACCs are positively linked with the quality of financial reporting. The efficacy of corporate $\mathrm{AC}$ in monitoring the financial reporting practice relies on the independence of $\mathrm{AC}$ members [1] accounting and financial expertise [20, 24, 23], the number of meetings held [15] and size of AC [25].

The configuration of AC is less strict in Jordan compared to developed nations [26, 27]. Furthermore, in 2004, instituting ACs became obligatory for corporates listed in the Jordan Securities Commission (JSC). Accordingly, ACs are remained the latest form of $\mathrm{CG}$ to be used in Jordan in line with JCGC (2017) which form ACs which stated that ACs should consist of three non-executive members, and at least two must be independent members who have no relationship with the corporate. In such that, they will not meddle with the application of their independence on the management and the firm, and one among them must chair the committee. There are about 248 number of public shareholding corporates in Jordan in practice, who are all mandated to form ACs. A contemporary survey by the investigator regarding firms that have listed their AC with the JSC the finding indicates $85 \%$ of the total companies who had done so. Nevertheless, there is a scarce of knowledge about the real functions of $\mathrm{AC}$ in these firms. AC not only plays a vital supervising role but also ensures the quality of financial statements and company accountability [28]. Disappointingly, AC in Jordan are commonly created to meet the requirements and standards of the regulations instead of having an indispensable role in sustaining the accuracy and reliability of the financial reporting scheme [29-32], this study is taking these aspect considerations.

Conversely, compliant accruals are an indirect determination of the quality of financial reporting. The audit opinion is an appropriate indicator for the quality of financial reporting [33]. Consistent with Farinha \& Viana, [5] issuing of a modified opinion by an external auditor is regarded as a sign of the poorer quality of financial reporting. Yet, there are very scarce studies, which reported the modified audit opinions as an aspect of quality of financial reporting. Only countable scholars employ audit opinion as a substitute for the quality of financial reporting $[5,34,35]$. Other studies have employed the audit opinion as a proxy for the quality of financial reporting [35-38, 5].

Likewise, studies have explored the characteristics of AC (independence, meetings, and size) on the modified audit opinion $[38,35]$. However, these studies have overlooked the significance of other characteristics such as AC expertise, this is because the success of AC involves aggregate of characteristics [39]. In such that efficacy of one mechanism depends on the success of others. These tools function as complementary to each other in safeguarding the stakeholders' interests and improve the quality of financial statements $[40,41]$. Despite various literature on ACCs, but little is known about either its role in reducing the attitude of the firm to obtain the modified audit opinion and improving quality of financial reporting or its involvement in developing countries, for instance, Jordan, where $C G$ is poor $[39,42,14]$.

The present study aims at filling these research gaps, and it is significant to explore this crucial issue employing a more current sample. Literature has shown that ACCs affect the quality of financial reporting, proxy through earning management $[20,16$, $6,7,17]$.

In this paper, the impact of the ACCs on the modified auditor opinion (MAO) in Jordan is investigated exploring the relationship between the ACCs (expertise, independent, meeting, and size) and the provision of MAO among listed corporates in Jordan. This present investigation encompasses the study on quality of financial reporting utilizing audit opinion as a determination for the quality of financial reporting and assesses its correlation with ACCs.

Furthermore, this study adds to the pool of knowledge in various ways. One, it fills the gap about the influence of ACCs on modified audit opinion in Jordan. Two, it offers the policymakers with empirical data and vital information regarding ACCs activities and factors that influence such activities in Jordan in connection to MAO. Three, it provides researchers, policymakers, and the public with information financial reporting standards in correlation with the provision of MAO among listed corporates in Jordan. Four, it offers direction and support for components of companies and policymakers regarding their relative significance in safeguarding the quality of financial statements through ACCs. Five, it is one of the first studies to address the relationship between $\mathrm{AC}$ and modified audit opinion (in term of proxy on quality of financial reporting) in Jordan, Six, it offers an empirical suggestion on the efficacy of the AC to enrich the quality of CG. To the best knowledge of the current researcher, this work symbolizes the first attempt to investigate the relationship between ACCs and modified audit opinion in a developing economy. The findings have 
policy inferences in enhancing CG efficacy and success concerning quality financial statements.

\section{Literature Review and Hypotheses Development}

\subsection{Contextual Auditor's Reporting in Jordan}

Audit statements reporting do internal or external auditors to update the public regarding their auditing activities [11] utilize utmost communication instrument. Hence, auditor's reporting is a prospective way to validate the authenticity and accessibility of financial facts [43]. Thus, an audit opinion is the financial report that conveys the assessment of independent auditors to their employers or consumers as an outcome of their investigation [44]. The audit opinion is very crucial because it informs the shareholders or investors on the real situations of matters on a corporate through the financial statements on whether the facts are reliable or not [45]. It as well indirectly updates to the clients of financial reports how the reliable and honest are the top board management [46].

AL-Thuneibat, [47] described the content of the auditor's statement as a financial detail or testimony which encompasses several values and suggestions that can be trusted, accepted, and applied to make various financial decisions. Also, the facts containing in the auditor's statement can offer a valuable contribution to the client's analysis of the financial reports during decision-making on the economy. Additionally, the audit statement can encompass practical facts concerning the corporate's capability to maintain its activity. Based on corporate law in Jordan for all listed firms on the ASE were required to submit financial reports from the external auditors. This is displays the impartiality of financial statements by corporates in conveying their operating outcomes and its financial status. The 1997 corporate law article no. 196 mandated the following information must be incorporated in the company auditors' reports;

That the auditor has obtained the knowledge, statements, and explanations he considered indispensable to execute his responsibility.

That the corporate must upholds structured accounts registers and official papers. Its financial reports must be organized in conformity with the global standard of accounting and auditing codes which can rightly display the financial status of the company, its cash flow, balance sheet, and profit and loss account conform to the records and books.

That the auditing processes conducted by the auditor for the corporate accounts, form in his opinion, a satisfactory realistic basis to convey his opinion concerning the corporate financial situation, outcomes of its processes, and cash flow in compliance with international standard auditing rules.

That the financial reports included in the board of director's statement forwarded to the general meeting comply with the corporate records and registers.

There are two key classes of opinions in Jordan: modified (qualified) and unmodified (unqualified) audit opinions. The modified audit opinion is divided into four subclasses:

Unqualified with an explanatory paragraph

Qualified opinion reports

Disclaimer of opinion reports

Adverse opinion reports

Based on the corporates' law 22/1997 /article (195/b), following this categorization above, the external auditor must provide an opinion on the firm's financial reports on one of the subsequent ways:

Absolute approval (unmodified /unqualified opinion),

Approval with reserve (modified/qualified opinion) however the auditor must specify the details for such a reservation and its financial consequence on the firm,

Non-approval (adverse or disclaimer opinion), the auditor must return the financial reports to the firm's board of directors with the explanations that justify the rejection.

\subsection{Independence of Audit Committee}

Independence $\mathrm{AC}$ indicates the degree to which the $\mathrm{AC}$ is not under the control of corporate management [48]. When the $\mathrm{AC}$ is largely colonized by board members, the financial statement can be at risk of unfairness or partiality [7]. Thus, Bronson et al. [1] and DeFond and Francis [49] revealed that the implicit benefit of enhanced AC independence sprout from the belief that independent directors are better overseers of management than internal directors. This is to guarantee that ACs supply adequate supervision over the auditing practice and quality of financial statement [48]. According to this squabble, earlier study shows that AC independence is positively associated with effectual supervision of the process of financial reporting [1]. According to the agency theory perspective, an independent $\mathrm{AC}$ can solve the agency issue and lessen its costs [50]. The efficacy of the AC pivots on the level of its independence $[1,51]$. Other scholars who established a link between a higher quality of financial reporting and $\mathrm{AC}$ independence [51] reinforce this argument. AC independence is deemed critical in supervising the quality of the financial report [16]. Apart from this, earlier study shows that ACs with independent members in boards of directors are more successful safeguarding the auditor's independence [52, 15]. In accordance with Hayes, [53] and Bajra \& Čadež, [7] demonstrated that the independence is preferred from the financial statement opinion since independent members are more expected to convey a fair opinion regarding financial reporting practices compared to dependent members.

It seems that negligible empirical study on the correlation between the independent of AC and modified audit opinion has been published so far (at least to the best knowledge of this investigator). De Vlaminck \& Sarens [16] depicts that AC independence is positively and significantly associated with quality of the financial report, whereas, Chen \& Zhang, [51] shows that negative association between earnings management and the AC independence. Moreover, PuchetaMartínez \& de Fuentes [38] discover that AC independence is a negatively significant relationship at the $10 \%$ level with 
the reforms of audit opinion for noncompliance with GAAP. Antagonistically, this study did not discover any correlation between $\mathrm{AC}$ independence and quality of financial reporting $[54,4,15,9]$.

However, the relationship between $\mathrm{AC}$ independence and modified audit opinion in Jordan remains unclear. The JCGC (2017) supports the significance of AC independence to be segregated from the executive directors' membership. Hence, as stipulated in Article (7) in JCGC (2017), the AC should consist of at least three non-executive directors which at least two of whom should be independent members and the committee should be head by one of them. The independent AC members are anticipated to be liable in circumventing the listed public companies in Jordan with the prospect to obtain a modified audit opinion. This research attempts to exam the effect of the independent of $\mathrm{AC}$ on the modified audit opinion. Therefore, the subsequent hypothesis is proposed:

H1: There is a negative association between audit committee independence and the prospect that a company receives a modified audit opinion.

\subsection{Size of Audit Committee}

Recently, Buallay \& AlDhaen, [22] claimed that a larger $\mathrm{AC}$ is the more efficient which is because of the fact that they consist of members with different knowledge and expertise to function more dependably in supervising financial processes. This is because a large number of AC members are more probably to assist a committee to uncover and resolve matters and problems in company reporting practices [55, 56, 22]. Besides, the more diverse, expertise, and competencies they are, the more assurance are their supervising roles and activities [55]. Therefore, ACs with more members can function better and more successfully as overseeing mechanism thereby averting the corporates from obtaining a modified audit opinion.

The past study emphasizes that the size of the $\mathrm{AC}$ has a positive influence on the efficacy of the AC to supervise the quality of financial reporting $[25,56,21]$. This is due to the fact that when $\mathrm{AC}$ has satisfactory members with the various experience they tend to carry out more thorough supervision of financial statement because they have potential to offer an indispensable strength and variety of opinions and expertise to safeguard the effectual overseeing process of financial reporting [56-58]. This offer better strengthens the $\mathrm{AC}$ in their overseeing task, which, in turn, can result in a higher quality of financial statements $[16,7,23]$, avert auditor's incongruities with the management [59, 48, 60], and decreases the prospect of receiving a modified audit opinion.

Nevertheless, the relationship between AC size and modified audit opinion is yet to be clear. Empirical researches showed conflicting results with respect to the influence of AC size on the quality of financial reporting. Some of these showed that the size of the AC has a substantial negative relationship with the quality of financial reporting $[4,9]$. This suggests that the big size of $\mathrm{AC}$ would have superior control and overseeing role that has the potential to transform into a better quality of financial statements because of more participation and ideas. Whereas Salehi \& Shirazi, [21] discovered that AC size is positively connected with the quality of financial disclosure of the firm. However, it has been stated that $\mathrm{AC}$ size has an insignificant relationship with quality of financial report [60, 16], and earnings management [19]. Furthermore, Pucheta-Martinez and De Fuentez [38] empirical study carried out in Spain claimed that the size of $\mathrm{AC}$ and the proportion of independent members significantly impact the reception of audit reports that comprise non-compliance or error qualities. The findings of these authors further showed a nonsignificant relationship between the AC size and the issuing non-compliance or error practiced statements.

With the aim of increasing the AC effectiveness, it must have a satisfactory number of committee members to execute its function. In the Jordanian context, the relationship between $\mathrm{AC}$ size and modified audit opinion still remains unclear. The JCGC (2017) obligate that AC must comprise of at least three directors. Thus, the literature indicates that $\mathrm{AC}$ size can be the auditor makes a key impact on the likelihood that modified opinion, however with an anticipated indication that this can be either positive or negative. This inspires the formulation of the second hypothesis as follow:

$\mathrm{H}_{2}$ : There is a relationship between the firms with a higher number of audit committee members which may less (more) likely to receive modified audit opinion.

\subsection{Meeting of Audit Committee}

According to earlier empirical evidence, the number of AC meetings mirrors their supervising efficiency [55, 22]. The number of meetings is the main component in the dependability and efficacy of a corporate's undertakings and practices [22]. The number of meetings conducted by AC is directly associated with enhancements in the quality of financial reports $[15,16]$. This is because more meetings held by the AC can boost their efficacy and provide more successful supervision for company financial statement [4], including planning and writing of firm financial activities. Consequently, the chance of receiving a modified audit opinion will be reduced $[38,15]$.

Conversely, the relationship between a number of $\mathrm{AC}$ meetings and modified audit opinion is yet to be clear. de Andrés Suárez et al. [15] discovered that the number of AC meetings significantly and positively affects the quality of the financial reports. This suggests that the number of $\mathrm{AC}$ meetings was linked with a lower prospect of modified opinions (greater quality of financial statement). Therefore, Sierra et al. [61] and García, Barbadillo \& Pérez [4] stated that a negative relationship between the size and number of AC meetings and quality of financial statements as measured by discretionary accruals. Salehi \& Shirazi, [21] show that the number of AC meetings held in the financial year is negatively linked with the quality of company disclosure. Likewise, Allegrini and Greco [62] displayed that the number of AC meetings is significantly connected with the quality of firm reporting. Pucheta-Martínez \& De Fuentes, [38] established that AC in Spain is partly efficient in ensuring a 
higher quality of the financial statement. De Vlaminck \& Sarens [16] found a negative and insignificant relationship between AC meeting and the quality of financial reporting. In addition, Khlif and Samaha [8] depicted that AC meetings improve the internal mechanism.

The relationship between AC meetings and modified audit opinion is still vague. In line with the JCGC (2017) which offers that, corporates must have their AC meetings with a minimum of four times a year (JCGC, 2017). Consequently, the following hypothesis is proposed:

$\mathrm{H}_{3}$ : There is a negative association between the frequency of audit committee meetings and the prospect that a company receives a modified audit opinion.

\subsection{Expertise of Audit Committee}

A vital measurement for AC success, which attracted the consideration of supervisors and researchers, is the financial expertise of AC members. Fiscal expertise suggests that $\mathrm{AC}$ members should possess skill and experience in accounting and finance [7]. Consistent with the agency theory, the existence of members with fiscal expertise improves committee efficacy in executing monitoring responsibilities [63]. This is because AC members with experts in the discipline and have sufficient knowledge are more prospective in identifying irregular accounting and auditing performance compared to members who are lacking in these areas [64]. Bedard and Gendron [55] detailed that financial expertise permits $\mathrm{AC}$ members to classify and deliberate on the matter that tasks the managers and external auditors to a higher scope of the financial statement. This process is anticipated to increase the clarity and reliability of company reporting [22]. However, researches have exhibited that when the presence of members of the $\mathrm{AC}$ with proper experience is deemed a vital input to the efficacy of the $\mathrm{AC}$, and thus, with an improved experience of the $\mathrm{AC}$, can be more successful in monitoring the financial statement of the firm [55, 20]. Hence, they appropriately monitor complex explicit accounting problems, can enhance the efficacy of the AC in supervising the practice of financial reporting [55, 64, 20, 16, 17], and as a result, reducing the prospect of getting a modified audit opinion.

Past studies indicate that the professional competence of the committee is an important element affecting the reliability of financial reports $[65,58,51,59]$. Krishnan and Visvanathan [60] ascertained that the AC members with expertise in accounting and auditing are in a better position to oversee the quality of financial evidence. Cohen et al. [20] indicate that $\mathrm{AC}$ members with expertise can enhance $\mathrm{AC}$ efficacy in supervising the process of the financial statement, which the expectation to the corporate to decrease the obtain prospect of modified audit opinion [5]. However, Chen \& Zhang, [51] and De Vlaminck \& Sarens [16] ascertains the insignificant negative link between AC accounting expertise and quality of financial reports. Rainsbury et al. [66] establish no significant relationship between the AC's expertise and quality of the financial report. In comparison, Chen \& Komal [23] and Kusnadi et al. [9] disclosed that the quality of financial reporting is positively and significantly linked with the existence of accounting expertise in AC. Also, Hayes [53] and Badolato et al. [24] discover a positive relationship between financial expertise and the quality of the report. Kusnadi et al. [9] discern that ACs independence improves the quality of financial statement and that of committee with fraternized financial expertise inclines to be positively connected with financial reporting quality. DeFond $\&$ Francis [49] showed the positive market response to the choice of accounting financial experts consigned to AC, as it is considered that they can assist in enhancing the AC's capability to ensure high-quality reporting.

Nevertheless, the relationship between AC expertise and modified audit opinion remains unclear. Earlier studies have stressed the importance of the features of the AC as the critical factors in increasing $\mathrm{AC}$ efficacy in its supervising role in order to safeguard the quality of financial statement $[55,64,20$, $51,16,22,7,23,63]$. This result in the conclusion that AC financial expertise appears to assume more effective monitoring activities improves committee efficacy in acting and overseeing responsibilities, and has more impact on the financial reporting, then consequently lessens the prospect of a corporate receipt of a modified audit opinion.

In the Jordanian context, the JCGC (2017) necessitates all the $\mathrm{AC}$ members to be competence in financial and accounting affairs. Furthermore, at least one of whom should have preceding work experience in accounting or financial affairs or be a holder of a scientific requirement or a proficient certificate in accounting, finance, etc. Also, the code requires that all members of the $\mathrm{AC}$ should be skilled in reading, evaluating, and deducing financial information in order to accomplish their tasks efficiently. Debatably, the JCGC 2017 requires the AC members to have a sufficient cognizing of accounting affairs and matters linking with a financial statement.

Consequently, it could be assumed that elevation of members in financial expertise will boost the AC's capability to supervise the management [24], provide better supervision and to successfully analyze the practices [67], and guarantee the external auditor's work efficiently embarks on [68], hence, would result in better internal control in the corporate and better quality of financial report [63]. Accordingly, there would be reduced in the occurrence of receipt of a modified audit opinion. Based on this rule coupled with the limited obtainable published work, this study tries to explore the influence of AC financial expertise on the modified audit opinion. Thus, the following hypothesis is proposed:

$H_{4}$ : There is a negative association between the audit committee expertise and the prospect that a company receives a modified audit opinion.

\section{Research Design and Methodology}

\subsection{Sample Selection and Description}

The industry and services divisions are samples in this study. We select these sectors because industrial and service measured as a vital role for economic development [69], and 
also due to the fact that numerous Jordanian corporates in these sectors have previously experienced bankruptcy following the corporate crises. This study uses data from 2012 to 2017 after the issuance of the CG code of 2009 in Jordan. We selected these periods (i.e. 2012 to 2017) because the data are accessible and enough to achieve the purpose of this research [70]. We removed the financial sector from this sample, because of their distinctive features and their particular guidelines and requirements for annual reports. It is abiding by guidelines of governance published by the central bank and the insurance regulatory act, which vary from that of public shareholding corporates, which may have an influence on the results. The corporates with missing data were removed. The study samples comprised one hundred and seventeen (117) corporates that had the accessible data required for this research. The samples are firm-year observations from the 2012 to 2017 period. Data regarding $\mathrm{AC}$ and modified audit opinion were collected from the published annual reports for the listed corporates by the JSC. The audit opinion is applied as a measure for the quality of financial reporting. According to this data from the audit opinion reports of these corporates, most of these listed firms in Jordan received modified audit opinions from 2012 to 2017 which match with the lower quality of financial reporting.

The categories of modified audit opinion as received by Jordanian corporates during the period of 2012 to 2017 are presented in Table 1. The data are categorized into qualified (56\%), unqualified with explanatory paragraph (42.66\%), adverse opinion $(0.44 \%)$, and disclaimer opinion $(0.44 \%)$. Overall of $32.89 \%$ of the annual report of Jordanian corporates received a modified audit opinion between 2012 to 2017 periods, which shows the lower quality of financial reporting from these Jordanian corporates. However, this is higher compared to Chinese listed corporates (11\%), Britain (2.96\%), and other East Asian economies (2.01\%).

Table 1. The Categories of Modified Audit opinion as Received by Jordanian Companies from 2012 to 2017.

\begin{tabular}{|c|c|c|c|c|c|c|c|c|}
\hline Type of Modified Audit Opinion & 2012 & 2013 & 2014 & 2015 & 2016 & 2017 & Total & Percentage \\
\hline Qualified & 19 & 19 & 22 & 24 & 24 & 19 & 127 & $56 \%$ \\
\hline unqualified with explanatory paragraph & 14 & 18 & 18 & 15 & 14 & 17 & 96 & $42.66 \%$ \\
\hline adverse opinion & 0 & 1 & 0 & 0 & 0 & 0 & 1 & $0.44 \%$ \\
\hline disclaimer opinion & 0 & 0 & 0 & 1 & 0 & 0 & 1 & $0.44 \%$ \\
\hline Total & 33 & 38 & 40 & 40 & 38 & 36 & 225 & $100 \%$ \\
\hline
\end{tabular}

\subsection{Model and Variables}

To achieve test this, we apply the following logistic regression models (algorithm model) for the probability that the external auditor can issue a modified audit opinion for the four hypotheses:

$$
\begin{gathered}
\mathrm{MAO}=\beta 0+\beta_{1} \text { ACIND }+\beta_{2} \text { ACSIZE }+\beta_{3} \text { ACMEET }+\beta_{4} \text { ACEXPE }+\beta 4 \text { LogAuLag }+\beta_{5} \operatorname{LogAF}+\beta_{6} \text { BIG } 4+\beta_{7} \mathrm{LEV}+\beta_{8} \\
\text { LNASSETS }+\beta_{9} \text { Loss }+\beta_{10} \text { Prior Report }+\varepsilon
\end{gathered}
$$

The variables measured in this model are described in Table 2.

\begin{tabular}{|c|c|c|}
\hline Variable & & Measurement \\
\hline Modified Audit opinion & MAO & 1 , if a company received a modified audit opinion, otherwise 0 . \\
\hline AC independent & ACIND & the proportion of independent directors on the $\mathrm{AC}$ \\
\hline $\mathrm{AC}$ size & ACSIZE & Number of AC members \\
\hline AC meeting & ACMEET & Number of audit committee meetings held annually \\
\hline $\begin{array}{l}\text { Financial Experience of Audit } \\
\text { Committee Members }\end{array}$ & ACEXPE & $\begin{array}{l}\text { The financial experience of the } \mathrm{AC} \text { measured by dividing the number of qualified } \\
\text { members in accounting financial and banking management by all members. }\end{array}$ \\
\hline Audit Report Lag & ARLLN & The logarithmic of audit report lag \\
\hline Audit Fees & Audit Fees LN & The logarithmic of external audit fees \\
\hline Audit Firm Size & BIG4 & Dummy variable that is equal to 1 if the auditor is a Big 4 and 0 otherwise \\
\hline Leverage & LEV & The total liabilities divided by the total assets of firm $\mathrm{i}$ in year $\mathrm{t}$ \\
\hline Loss & Loss & $\begin{array}{l}\text { Dummy variable that is equal to } 1 \text { if the firm reported losses in the previous year, and } 0 \\
\text { otherwise }\end{array}$ \\
\hline Previous Audit Report & AOPRIOR & $\begin{array}{l}\text { Dummy value ( } 1 \text { if the company received the same qualification in the previous and } \\
\text { the current year; } 0 \text { otherwise) }\end{array}$ \\
\hline
\end{tabular}

Table 2. Variables Measured in the model.

The major purpose of auditor work is to obtain practical guarantee as to whether the financial reporting, as a total, are devoid of document measurable misappropriation, so as the auditor is capable to express his/her opinion on the financial reporting without hindrance. The subsequent table (Table 3) explicates the reasons why the external auditor issued a modified audit opinion. According to ISA [71; 72], the external auditor issue a modified audit opinion because of three reasons; one, the inadequacy of the proper audit proof. Two, it is going concern opinion. Three, it is a mixture of reasons inadequacy of the proper audit-proof and going concern opinion. We discover that large portion of the corporates in Jordan gotten a modified audit opinion due to the inadequacy of the proper audit proof (also known as a drawback of the audit scope), which shows the lower quality of their financial statement. Therefore, a modified audit opinion can be a direct proxy for the quality of financial 
reporting. Obtaining and detailing satisfactory proof on which to center the auditor's opinion is one of the key purposes of an audit of financial reports. Approximately, $32.63 \%$ of corporates in Jordan received a modified audit opinion due to the going concern opinion emanating from the external auditor. About $18.9 \%$ of corporate annual observation received a modified audit opinion as a result of both inadequate proof and going concern.

Table 3. Reasons for Modified Audit opinions.

\begin{tabular}{lllllllll}
\hline & $\mathbf{2 0 1 2}$ & $\mathbf{2 0 1 3}$ & $\mathbf{2 0 1 4}$ & $\mathbf{2 0 1 5}$ & $\mathbf{2 0 1 6}$ & $\mathbf{2 0 1 7}$ & Total & percentage \\
\hline $\begin{array}{l}\text { Inadequacy } \\
\begin{array}{l}\text { Going } \\
\text { concern } \\
\text { opinion }\end{array}\end{array}$ & 20 & 21 & 16 & 18 & 18 & 14 & 107 & $47.55 \%$ \\
$\begin{array}{l}\text { Both } \\
\text { Total }\end{array}$ & 3 & 5 & 11 & 7 & 9 & 6 & 41 & $18.22 \%$ \\
\hline
\end{tabular}

\section{Results and Discussion}

In Jordan, there is a growing interest in the external audit, as many of the business individuals in Jordan, irrespective of their legal type or size, are necessitate to have an external audit and to make their audited financial statements available to the people. Consequently, the findings of this provide detailed on the impact of ACCs on the modified auditor opinion in Jordan by exploring the relationship between the ACCs and the provision of the MAO among listed corporates in Jordan. In links with a research question, does the ACCs impact modified auditor opinion in Jordan?

We employed descriptive statistics in this part to express variable used in this study. Table (4) displayed the mean of AC independent 0.30 ranges from 0 to 1 . JCGC (2017) emphasizes the significance of AC that should encompass at least three non-executive directors, two of whom should be independent members and should head by one of them. The mean of $\mathrm{AC}$ size is approximately 3.18 and it ranges from 2 to 7, and based on Jordanian code of CG, at least three members must be designated in the $\mathrm{AC}$, this suggests that most of the corporates in Jordan followed (embraced) this regulation. Regarding the number of meetings, there should not less than 4 meetings per annum according to JCGC, where the number of meetings obtained range between 1-13 meetings with 4.52 mean. This suggests that most of the corporates in Jordan are obviously adopted this code. Further, AC financial expertise in accordance with JCGC (2017) necessitates at least one of AC members must have previous working experience with a background in accounting or financial matters or had a scientific qualification, or a professional certificate in accounting, finance, or other related areas. The mean of $\mathrm{AC}$ financial expertise is between $0-0.75$, while the mean for member expertise is 0.23 . This shows that most AC members in these corporates in Jordan have no appropriate experience required. The modified audit opinion score means is 0.23 ranges between 0 and 1 . This implies a lower quality of financial reporting these corporates in Jordan, which is greater compared to those of Chinese listed companies (11\%), Britain (2.96\%), and other East Asian economies (2.01\%).

Table 4. Sample Selection and Description.

\begin{tabular}{llllll}
\hline Variable & Obs & Mean & Std. Dev. & Min & Max \\
\hline $\begin{array}{l}\text { Modified Audit } \\
\text { opinion }\end{array}$ & 686 & 0.23 & 0.42 & 0 & 1 \\
ACIND & 686 & 0.30 & 0.21 & 0 & 1 \\
ACSIZE & 686 & 3.18 & 0.55 & 2 & 7 \\
AC meeting & 686 & 4.52 & 1.14 & 1 & 13 \\
AC expertise & 686 & 0.23 & 0.22 & 0 & 0.75 \\
Audit Report Lag LN & 686 & 12.90 & 22.41 & 1.79 & 138 \\
Audit fees LN & 686 & 9.26 & 0.87 & 1.50 & 11.99 \\
Big4 & 686 & 0.77 & 0.42 & 0 & 1 \\
leverage & 686 & 66.53 & 356.46 & 0.01 & 4995.11 \\
LOSS & 686 & 0.41 & 0.49 & 0 & 1 \\
Previous audit report & 686 & 0.21 & 0.41 & 0 & 1 \\
\hline
\end{tabular}

\subsection{Analysis of Logistic Regression Correlation Analysis (Pearson Correlation Matrix) for Variables}

The result of correlation analysis for variables is displayed in Table 5. According to Midi et al. [73], the common rule of thumb is that if the correlation coefficient between two regressors is greater than 0.8 , the multicollinearity is a serious issue. The correlations are relatively low, mostly under 0.30 apart from the previous audit report, which is $0.73 \%$ with $0.01 \%$ level of significant characterized by positive direction. This indicates that multicollinearity is not an issue in either of the model valuations. It implies that the corporates with previous audit report are more probable to obtain a modified audit opinion. The correlation-matrixes emphasize that the estimates of correlation realized for the variables in the modified audit opinion are less than 0.80 . This suggests that there is nonexistence of multicollinearity among the descriptive variables in the models. The highestcorrelation among the independent variables is 0.31 for a modified audit opinion. All these variables have their correlation less than critical limits of 0.80 (Tables 5). This offers the suggestion that multicollinearity is not an issue in either of the model estimates.

The Pearson coefficients of correlations between the dependent variable (Persistence) demonstrating the conservation or improvement in the unnecessary qualifications and the group of independent variables elucidates our hypotheses. Concerning the first hypothesis, the AC (independent variable) is positively correlated with our dependent variable. Also, we obtained an insignificant correlation between AC's size or meeting (variables) and the dependent variable. The AC expertise is negatively correlated with the dependent variable. This finding agreed with our fourth hypothesis and seems to show that the AC with the expertise adds to the enhancement of the reliability of financial reporting, thereby decrease the corporate obtaining the modified audit opinion. 
Table 5. Result of Correlation Analysis for Variables (Pearson Correlation Matrix).

\begin{tabular}{|c|c|c|c|c|c|c|c|c|c|c|c|}
\hline Variable & MAO & AC IND & AC SIZE & AC meeting & $\begin{array}{l}\text { AC } \\
\text { expertise }\end{array}$ & $\begin{array}{l}\text { ARL } \\
\mathbf{L N}\end{array}$ & $\begin{array}{l}\text { Audit fees } \\
\text { LN }\end{array}$ & Big4 & leverage & LOSS & $\begin{array}{l}\text { Prior audit } \\
\text { report }\end{array}$ \\
\hline МАО & 1 & & & & & & & & & & \\
\hline ACIND & $0.0634 *$ & 1 & & & & & & & & & \\
\hline ACSIZE & 0.045 & $-0.0681^{*}$ & 1 & & & & & & & & \\
\hline $\begin{array}{l}\mathrm{AC} \\
\text { meeting }\end{array}$ & 0.0344 & 0.0372 & $0.2094 * * *$ & 1 & & & & & & & \\
\hline $\begin{array}{l}\mathrm{AC} \\
\text { expertise }\end{array}$ & $-0.0783 * *$ & $0.0727 * *$ & $\begin{array}{l}- \\
0.1382 * * *\end{array}$ & -0.0348 & 1 & & & & & & \\
\hline ARL LN & -0.0068 & 0.0271 & -0.0595 & $-0.0863 * *$ & 0.048 & 1 & & & & & \\
\hline $\begin{array}{l}\text { Audit } \\
\text { fees LN }\end{array}$ & $-0.0888 * *$ & $-0.0791 * *$ & $0.1968 * * *$ & $0.2503 * * *$ & -0.0239 & 0.0348 & 1 & & & & \\
\hline Big4 & 0.0096 & $-0.1249 * * *$ & $0.0817 * *$ & 0.0523 & 0.0451 & 0.0066 & $0.2431 * * *$ & 1 & & & \\
\hline leverage & 0.0181 & 0.050 & -0.0071 & 0.0176 & -0.0064 & 0.0223 & $-0.1988 * * *$ & $-0.2124 * * *$ & 1 & & \\
\hline LOSS & $0.2924 * * *$ & 0.0356 & -0.0003 & 0.0165 & $-0.1261 * * *$ & 0.0295 & $-0.1772 * * *$ & $-0.0985 * * *$ & $0.1209 * * *$ & 1 & \\
\hline $\begin{array}{l}\text { Prior audit } \\
\text { report }\end{array}$ & $0.737 * * *$ & $0.0753 * *$ & -0.0603 & -0.0202 & -0.0061 & -0.0033 & $-0.0966^{* *}$ & -0.0176 & -0.0293 & $0.2489 * * *$ & 1 \\
\hline
\end{tabular}

\subsection{Logistic Regression Analysis}

Table 6 present the results of the logistic regression. The model contains independent variable AC (expertise, independence, meeting, and size) and control variables (audit report lag LN, audit fees LN, audit firm size, big4, Leverage, loss, and previous audit report) with modified audit report as the dependent variable. The result showed the Pseudo $\mathrm{R}^{2}$ report at $50 \%$, the Wald $\operatorname{chi}^{2}(10)$ test reports at 202.99 and the model is significant at $0.00(\mathrm{p}<0.01)$ level.

Table 6. Result of Logistic Regression.

\begin{tabular}{llll}
\hline Modified audit opinion & Coef. & $\mathbf{z}$ & $\mathbf{P}>\mathbf{z}$ \\
\hline AC IND & 0.423 & 0.49 & 0.628 \\
AC SIZE & 0.587 & 2.70 & $0.007^{* * *}$ \\
AC meeting & 0.137 & 1.34 & 0.180 \\
AC expertise & -1.378 & -2.41 & $0.016^{* *}$ \\
ARL LN & 0.000 & -0.05 & 0.957 \\
audit fees LN & -0.156 & -0.88 & 0.379 \\
Big4 & 0.531 & 1.74 & $0.082^{*}$ \\
Leverage & 0.000 & 1.28 & 0.199 \\
LOSS & 1.064 & 3.64 & $0.000^{* * *}$ \\
Prior audit report & 4.354 & 13.79 & $0.000^{* * *}$ \\
cons & -4.516 & -3.12 & $0.002^{* * *}$ \\
Number of obs & 686 & & \\
Wald chi2 (10) & 202.99 & & \\
Prob $>$ chi2 & 0.000 & & \\
Pseudo R2 & 0.5019 & & \\
\hline
\end{tabular}

With regards to a key variable, we noted that $\mathrm{AC}$ independence (AC IND) is not significantly related with modified audit opinion. These finding is not in agreement with our earlier anticipations as in hypothesis $\mathrm{H} 1$ and not in line with other earlier findings. De Vlaminck \& Sarens [16] and Alzoubi [14] revealed a positive association between AC independence and quality of financial statement, whereas Chen \& Zhang, [51] found a negative association between earnings management and the $\mathrm{AC}$ independence. PuchetaMartínez \& de Fuentes [38] disclosed that AC independence has a significantly negative relationship at the $10 \%$ level with the reforms audit opinion for noncompliant with GAAP. Conversely, the finding also in concord with various other findings $[54,4,15,9]$ who as well fail to found any significant association between $\mathrm{AC}$ independence and quality of financial reporting. These findings indicated that $\mathrm{AC}$ independence has no influence on the quality of financial reporting.

According to the results in Table 6, the size of AC has a significant effect on the modified audit opinion at $1 \%$ level. Nonetheless, the direction of effect is positive. This finding suggests that the size of $\mathrm{AC}$ is positively related to modified audit opinion. This is demonstrated that when the size of AC is increased, it may be harmful to the quality of financial reporting, which in turn, leads to increase in the prospect of corporates in Jordan to get the modified audit opinion. Therefore, the null hypothesis H1 is rejected. Further, this finding is in accordance with Kusnadi et al. [9] who reported a negative relationship between the size of $\mathrm{AC}$ and quality of financial reporting, exhibiting that increasing the size of $\mathrm{AC}$ can affect the quality of financial reporting. This finding controverted the result obtained by Pucheta-Martinez and de Fuentes [38] who found that the size of AC had an obvious influence on amended audit opinion. Likewise, PuchetaMartínez \& García-Meca, [34] found no significant association between $\mathrm{AC}$ size and modified audit opinion.

The number of $\mathrm{AC}$ meetings (AC meet) was not significantly related to MAO, thus hypothesis $\mathrm{H} 3$ rejected. This result is not consistent with initial anticipations in hypothesis $\mathrm{H} 3$ and controverted other reported findings. de Andrés Suárez et al. [15] showed that the number of AC meetings positively and significantly impacts the quality of the financial reporting, whereas García et al. [4] established a negative relationship between the $\mathrm{AC}$ size and number of meetings held by $\mathrm{AC}$ and quality of financial reporting. The finding supports the results obtained by Bédard et al. [58], Baxter \& Cotter [74]), and García et al. [4] who did not substantiate any relationship between $\mathrm{AC}$ meeting and earning quality. During the stakeholders' meeting in Jordan, stockholders could be presented with a range of appropriate services and estimated costs. They then could adopt for themselves what level of the declaration they are willing to pay for every year. This would serve not only to inform stockholders of an audit's likely limitations but also to 
educate them to the relative costs for augmented audit work that would result in increased levels of reassurance. Conversely, the General Meeting of Stakeholders is permitted to specify an index fee change. [15] offered proof that audit mandates in Jordan are frequently renewed. The author results indicated Jordanian Company Law necessitates that the annual general meeting takes place within six months after the closing of the fiscal year. Companies have to submit the financial statements to the Amman Security Exchange within thirty days after the annual general meeting of stakeholders. It is presumed that problem companies delay their annual general meeting, exceed the required compliance time of the financial statements, and thus are more probable to go bankrupt.

Lastly, the association between AC financial expertise (AC exp) and modified audit opinion, which was negative and significant at 5\% level, hence supported hypothesis H4. AC members with expertise, knowledge, and experience in accounting and finance (AC exp) will be more capable of correcting potential financial issues before they become bigger, this is due to the improved capability of AC members to ask and debate, and comprehend the solutions, then enhance the efficacy of the AC in supervising the process of financial reporting. Therefore, an AC with sufficient knowledge and skills in financial reporting has a higher tendency for decreasing the prospect of obtaining a modified audit opinion. This finding is in agreement with our initial anticipations in hypothesis H4, however, it opposes other earlier results obtained by Chen \& Zhang [51] and De Vlaminck \& Sarens, [16] who found no significant and negative association between AC accounting expertise and quality of financial reporting. Moreover, there are additional researches examine the relationship between $\mathrm{AC}$ financial expertise and managerial reporting quality in Jordan. [27] discovered a negative relationship between the existence of financial experts on $\mathrm{AC}$ and the occurrence of financial restatements in Jordan. [29] and [31] further indicated that AC financial expertise is positively connected with earnings quality in Jordan. [32] report a positive relationship between AC financial expertise and the quality of short-term disclosure. Comparison, [26] do not find a significant relationship between AC financial expertise and the quality of voluntary disclosure in Jordan. Financial expertise is considered fundamental to an AC's effectiveness because the committee needs to conduct several responsibilities that require a high level of financial/accounting complexity [30, 32]. Financial experts are therefore significant for achieving those responsibilities and protecting stakeholders' interests in relation to financial reporting quality [25].

With respect to control variables, we discovered that the audit report lag (ARL LN) displayed a positive but insignificant relationship with modified audit opinion. This mean shows that auditors spend more time and effort in their auditing duties before the issuance of a qualified opinion; this is concord with Tsipouridou \& Spathis [75] and Sultana et al. [19]. The auditor needs to consider whether the matter causing the qualification and influencing the opinion on other matters indicated by the Companies Act in Jordan. If, the audit report represents the inventory balance or indeed related balances, for instance, costs of sales, working capital or net assets as itemized in the financial statements, then whereas it may be consistent with the financial core audit matters excluding matter termed in the basis for qualified opinion section, there are no main audit matters to be communicated in the report. The other information comprises the information included in the annual report, other than the financial statements and our auditor's report thereon. The directors are responsible for the other information. Our opinion on the financial statements does not cover the other information and, except to the extent otherwise explicitly stated in our report, we do not express any form of assurance conclusion thereon. As highlighted by the findings, the long duration between the last of the financial year of a corporate and the date of the audit report increases the prospect of corporates in Jordan in receipt of a modified audit opinion. The External audit fees (audit fees LN) had an insignificant association with modified audit opinion. This result discloses that external audit fees have no effect in improving the supervising processes, the quality of financial reporting. This, therefore, influences the opportunity of obtaining an unmodified audit opinion by the listed corporates in Jordan.

At the $10 \%$ level, the result showed a significant positive association between audit firm size (Big4) and the modified audit opinion. As expected, this result revealed that the audit firm size (Big4) improve the supervising process by improving the quality of financial statement thereby influence on the decline prospect of listed corporates in Jordan in obtaining a modified audit opinion. This result is not consistent with Moalla [12] and Farinha \& Viana, [5] who could not found an existing relationship between audit report qualification or audit report reform and audit quality (Big-4/non-Big 4). The leverage (LEV) also has an insignificant association, this shows that the higher amount of leverage adds to the higher reception of modified audit report. This is in accordance with findings documented by studies $[62,16]$, although these results are did agreed with that of Moalla, [12] who found a positive association between leverage and audit report reform.

LOSS is positively and strongly significant related with the modified audit opinion at $1 \%$ level, which indicates that these listed corporates in Jordan with a loss in the foregoing year increase their modified audit opinion. The finding is in agreement with the results reported by studies $[76,5,77,75$, $78,12)$, who disclosed that corporates with accounting losses are more probable to obtain modified audit (unfavorable) opinions. It implies that modified audit opinion and loss have a relatively strong association with the supposition that loss has a crucial influence on the modified audit opinion. Earlier researches offered that there is a positive relationship between losses and the receiving of qualified audit statement $[38,79]$. The previous year's audit opinion (PRIORAR) variables showed positive and strongly significant with the modified audit opinion. Thus, these findings show that the probability of getting a modified audit opinion is positively 
related to companies that obtained a similar qualification in the earlier year as the present year. This is in line with results from Pucheta-Martínez et al. [35] and Pucheta-Martínez \& De Fuentes [38] who stated that there is a positive association between the previous year's audit opinion and modified audit opinion.

\section{Conclusion}

This work explores the relationship between the modified audit opinion and the internal company supervising mechanisms including the AC characteristics (independence, financial expertise, meetings, and size) in public listed corporates in Jordan. The ACs are bestowed with the capability to oversee the process of financial reporting thereby directly influence the quality of financial reporting, in turn, leads to decreasing prospect of Jordanian corporates in obtaining a modified audit opinion.

The findings of this study showed that AC independence and number of meetings were not significantly related to the modified audit opinion. However, this study found proof that in line with the role of the AC size and financial expertise of the $\mathrm{AC}$ in decreasing the prospect of Jordanian public listed companies in obtaining a modified audit opinion. This shows that the corporates with large AC size and AC members with superior expertise and knowledge in the field of accounting and auditing are more probably to obtain an unmodified audit opinion.

The audit markets and production are not covered. These are the major limitation of this study especially in the connection with MAO and financial reporting. The external audit fees had an insignificant association with modified audit opinion. This result discloses that external audit fees have no effect in improving the supervising processes, the quality of financial reporting. This, therefore, influences the opportunity of obtaining an unmodified audit opinion by the listed corporates in Jordan.

Based on these limitations, this study suggests that future studies should look at AC financial expertise on the MAO by extending it to include audit markets and production. In a situation when the auditor's opinion is qualified, attention should be given to whether the other facts are also influenced by the similar matter as, or a related matter to, the mattergiving rise to the qualified opinion on the financial statements.

\section{References}

[1] Bronson, S. N., Carcello, J. V., Hollingsworth, C. W., \& Neal, T. L. (2009). Are fully independent audit committees really necessary?. Journal of Accounting and Public Policy, 28 (4), 265-280.

[2] Geiger, M. A., Raghunandan, K., \& Riccardi, W. (2013). The global financial crisis: US bankruptcies and going-concern audit opinions. Accounting Horizons, 28 (1), 59-75.

[3] Ellen, A., Angelina, C., \& Fenella, J. (2019). The Analysis of Auditor Opinion After Financial Crisis. KnE Social Sciences,
3 (11), 257-269.

[4] García, L. S., Barbadillo, E. R., \& Pérez, M. O. (2012). Audit committee and internal audit and the quality of earnings: empirical evidence from Spanish companies. Journal of Management \& Governance, 16 (2), 305-331.

[5] Farinha, J., \& Viana, L. F. (2009). Board structure and modified audit opinions: evidence from the Portuguese stock exchange. International Journal of Auditing, 13 (3), 237-258.

[6] Kibiya, M. U., Che-Ahmad, A., \& Amran, N. A. (2016). Audit committee independence, financial expertise, share ownership, and financial reporting quality: further evidence from Nigeria. International Journal of Economics and Financial Issues, 6 (7S), 125-131.

[7] Bajra, U., \& Čadež, S. (2018). Audit committees and financial reporting quality: The 8th EU Company Law Directive perspective. Economic Systems, 42 (1), 151-163.

[8] Khlif, H., \& Samaha, K. (2016). Audit committee activity and internal control quality in Egypt: Does external auditor's size matter?. Managerial Auditing Journal, 31 (3), 269-289.

[9] Kusnadi, Y., Leong, K. S., Suwardy, T., \& Wang, J. (2016). Audit committees and financial reporting quality in Singapore. Journal of business ethics, 139 (1), 197-214.

[10] Abu Qa'dan, M. B., \& Suwaidan, M. S. (2019). Board composition, ownership structure and corporate social responsibility disclosure: the case of Jordan. Social Responsibility Journal, 15 (1), 28-46.

[11] Habib, A. (2013). A meta-analysis of the determinants of modified audit opinion decisions. Managerial Auditing Journal, 28 (3), 184-216.

[12] Moalla, H. (2017). Audit report qualification/modification: Impact of financial variables in Tunisia. Journal of Accounting in Emerging Economies, 7 (4), 468-485.

[13] Bédard, J., Coram, P., Espahbodi, R., \& Mock, T. J. (2016). Does recent academic research support changes to audit reporting standards?. Accounting Horizons, 30 (2), 255-275.

[14] Alzoubi, E. S. S. (2019). Audit committee, internal audit function, and earnings management: evidence from Jordan. Meditari Accountancy Research, 27 (1), 72-90.

[15] de Andrés Suárez, J., García, E. C., Méndez, C. F., \& Gutiérrez, C. R. (2013). The effectiveness of the audit committee in Spain: implications of its existence on the auditor's opinion. SERIEs, 4 (3), 333-352.

[16] De Vlaminck, N., \& Sarens, G. (2015). The relationship between audit committee characteristics and financial statement quality: evidence from Belgium. Journal of Management \& Governance, 19 (1), 145-166.

[17] Garcia-Blandon, J., Argilés-Bosch, J. M., Martinez-Blasco, M., \& Merino, D. C. (2018). On the relationship between compliance with recommendations on the audit committee of codes of good practices and financial reporting quality. Journal of Management and Governance, 1-26.

[18] Zgarni, I., Hlioui, K., \& Zehri, F. (2016). Effective audit committee, audit quality, and earnings management: Evidence from Tunisia. Journal of Accounting in Emerging Economies, $6(2), 138-155$. 
[19] Sultana, N., \& Mitchell Van der Zahn, J. L. (2015). Earnings conservatism and audit committee financial expertise. Accounting \& Finance, 55 (1), 279-310.

[20] Cohen, J. R., Hoitash, U., Krishnamoorthy, G., \& Wright, A. M. (2013). The effect of audit committee industry expertise on monitoring the financial reporting process. The Accounting Reopinion, 89 (1), 243-273.

[21] Salehi, M., \& Shirazi, M. (2016). Audit committee impact on the quality of financial reporting and disclosure: Evidence from the tehran stock exchange. Management Research Reopinion, 39 (12), 1639-1662.

[22] Buallay, A. M., \& AlDhaen, E. S. (2018). The Relationship Between Audit Committee Characteristics and the Level of Sustainability Report Disclosure. In Conference on e-Business, e-Services and e-Society (pp. 492-503). Springer, Cham.

[23] Chen, S., \& Komal, B. (2018). Audit committee financial expertise and earnings quality: A meta-analysis. Journal of Business Research, 84, 253-270.

[24] Badolato, P. G., Donelson, D. C., \& Ege, M. (2014). Audit committee financial expertise and earnings management: The role of status. Journal of Accounting and Economics, 58 (2-3), 208-230.

[25] Hamdan, A. M., Mushtaha, S., \& Musleh Al-Sartawi, A. (2013). The audit committee characteristics and earnings quality: Evidence from Jordan.

[26] Al-Smadi, M. O. (2019). Corporate Governance and Risk Taking Of Jordanian Listed Corporations: The Impact of Board of Directors. Investment Management and Financial Innovations, 16, 1.

[27] Shbeilat, M. K. (2019). International Standard on Auditing No. 260 and Audit Quality: Evidence from Jordan. International Business Research, 12 (4).

[28] Al-Khaddash, H., Al Nawas, R., \& Ramadan, A. (2013). Factors affecting the quality of auditing: The case of Jordanian commercial banks. International Journal of Business and Social Science, 4 (11).

[29] Abdullatif, M. (2006). The effectiveness of audit committees in Jordanian public shareholding companies and potential company characteristics affecting it: perceptions from auditors in Jordan. Dirasat: Administrative Sciences, 33 (2), 450-467.

[30] Swaiti, M. (2006). A Proposed Model for the Role of Audit Committees in the Jordanian Public Shareholding Companies, and their Influence on the Effectiveness and Independence of External Audit. Unpublished Ph. D Thesis, Amman Arab University-Jordan.

[31] Al-Khadash, H. A., \& Al-Sartawi, A. A. M. (2010). The Capability of the Sarbanes-Oxley Act in Enhancing the Independence of the Jordanian Certified Public Accountant and its Impact on Reducing the Audit Expectation Gap" An Empirical Investigation from the Perspectives of Auditors and Institutional Investors". Jordan Journal of Business Administration, 6 (3).

[32] Alqatamin, R. M. (2018). Audit Committee Effectiveness and Company Performance: Evidence from Jordan. Accounting and Finance Research, 7 (2), 48.

[33] Danescu, T., \& Spatacean, O. (2018). Audit opinion impact in the investors' perception-empirical evidence on Bucharest
Stock Exchange. Audit Financiar, 16 (149), 111-121.

[34] Pucheta-Martínez, M. C., \& García-Meca, E. (2014). Institutional investors on boards and audit committees and their effects on financial reporting quality. Corporate Governance: An International Review, 22 (4), 347-363.

[35] Pucheta-Martínez, M. C., Bel-Oms, I., \& Olcina-Sempere, G. (2016). Corporate governance, female directors and quality of financial information. Business Ethics: A European Reopinion, 25 (4), 363-385.

[36] Carcello, J. V., \& Neal, T. L. (2000). Audit committee composition and auditor reporting. The Accounting Reopinion, 75 (4), 453-467.

[37] Pedro Sánchez Ballesta, J., \& Garcia-Meca, E. (2005). Audit qualifications and corporate governance in Spanish listed firms. Managerial Auditing Journal, 20 (7), 725-738.

[38] Pucheta-Martínez, M. C., \& De Fuentes, C. (2007). The impact of audit committee characteristics on the enhancement of the quality of financial reporting: An empirical study in the Spanish context. Corporate Governance: An International Reopinion, 15 (6), 1394-1412.

[39] Sultana, N. (2015). Audit committee characteristics and accounting conservatism. International Journal of Auditing, 19 (2), 88-102

[40] Al-Jaifi, H. A., Al-Rassas, A. H., \& Al-Qadasi, A. (2019). Institutional investor preferences: Do internal auditing function and audit committee effectiveness matter in Malaysia?. Management Research Review.

[41] García, L. S., Barbadillo, E. R., \& Pérez, M. O. (2019). Analysis of the Influence of the Internal Audit Function on Audit Fees. Revista de Contabilidad-Spanish Accounting Review, 22 (1), 100-111.

[42] Bataineh, H., Abuaddous, M., \& Alabood, E. (2018). The Effect of Family Ownership and Board Characteristics on Earnings Management: Evidence from Jordan. Academy of Accounting and Financial Studies Journal.

[43] Boolaky, P. K., \& Quick, R. (2016). Bank directors' perceptions of expanded auditor's reports. International Journal of Auditing, 20 (2), 158-174.

[44] Sirois, L. P., Bédard, J., \& Bera, P. (2018). The informational value of key audit matters in the auditor's report: Evidence from an eye-tracking study. Accounting Horizons, 32 (2), 141-162.

[45] Czerney, K., Schmidt, J. J., \& Thompson, A. M. (2019). Do investors respond to explanatory language included in unqualified audit reports? Contemporary Accounting Research, 36 (1), 198-229.

[46] Al-Othman, L. N. (2019). The Reaction Of The Financial Market On The Auditor Report: An Empirical Study On Service Companies Listed In Amman Stock Exchange (ASE). Investment Management and Financial Innovations, 16, 1.

[47] Al-Thuneibat, A. A., Khamees, B. A., \& Al-Fayoumi, N. A. (2007). The effect of qualified auditors' opinions on share prices: evidence from Jordan. Managerial Auditing Journal, 23 (1), 84-101.

[48] Bruynseels, L., \& Cardinaels, E. (2014). The audit committee: Management watchdog or personal friend of the CEO?. The Accounting Reopinion, 89 (1), 113-145. 
[49] DeFond, M. L., \& Francis, J. R. (2005). Audit research after sarbanes-oxley. Auditing: A Journal of Practice \& Theory, 24 (s-1), 5-30.

[50] Cohen, J. R., Krishnamoorthy, G., \& Wright, A. M. (2008). Form versus substance: The implications for auditing practice and research of alternative perspectives on corporate governance. Auditing: A Journal of Practice \& Theory, 27 (2), 181-198.

[51] Chen, J. J., \& Zhang, H. (2014). The impact of the corporate governance code on earnings management-Evidence from Chinese listed companies. European Financial Management, $20(3), 596-632$.

[52] Carcello, J. V., \& Neal, T. L. (2003). Audit committee characteristics and auditor dismissals following "new" goingconcern reports. The Accounting Reopinion, 78 (1), 95-117.

[53] Hayes, R. M. (2014). Discussion of "Audit committee financial expertise and earnings management: Journal of Accounting and Economics, 58 (2-3), 231-239.

[54] García Osma, B. G., \& Noguer, B. G. D. A. (2007). The effect of the board composition and its monitoring committees on earnings management: Evidence from Spain. Corporate Governance: An International Reopinion, 15 (6), 1413-1428.

[55] Bédard, J., \& Gendron, Y. (2010). Strengthening the financial reporting system: Can audit committees deliver?. International journal of auditing, 14 (2), 174-210.

[56] Li, J., Mangena, M., \& Pike, R. (2012). The effect of audit committee characteristics on intellectual capital disclosure. The British Accounting Reopinion, 44 (2), 98-110.

[57] Mohd Saleh, N., Mohd Iskandar, T., \& Mohid Rahmat, M. (2007). Audit committee characteristics and earnings management: Evidence from Malaysia. Asian Reopinion of Accounting, 15 (2), 147-163.

[58] Bédard, J., Chtourou, S. M., \& Courteau, L. (2004). The effect of audit committee expertise, independence, and activity on aggressive earnings management. Auditing: A Journal of Practice \& Theory, 23 (2), 13-35.

[59] DeFond, M., \& Zhang, J. (2014). A reopinion of archival auditing research. Journal of Accounting and Economics, 58 (2-3), 275-326.

[60] Krishnan, G. V., \& Visvanathan, G. (2008). Does the SOX definition of an accounting expert matter? The association between audit committee directors' accounting expertise and accounting conservatism. Contemporary Accounting Research, 25 (3), 827-858.

[61] Sierra, G. L,. Barbadillo, E. R,. Orta Pe'rez, M. (2012). Audit committee and internal audit and the quality of earnings: empirical evidence from Spanish companies. DOI 10.1007/s10997-010-9152-3.

[62] Allegrini, M., \& Greco, G. (2013). Corporate boards, audit committees and voluntary disclosure: Evidence from Italian listed companies. Journal of Management \& Governance, 17 (1), 187-216.

[63] Oussii, A. A., \& Boulila Taktak, N. (2018). Audit committee effectiveness and financial reporting timeliness: The case of Tunisian listed companies. African Journal of Economic and Management Studies, 9 (1), 34-55.
[64] Dhaliwal, D. A. N., Naiker, V. I. C., \& Navissi, F. (2010). The association between accruals quality and the characteristics of accounting experts and mix of expertise on audit committees. Contemporary Accounting Research, 27 (3), 787-827.

[65] Klein, A. (2002). Audit committee, board of director characteristics, and earnings management. Journal of accounting and economics, 33 (3), 375-400.

[66] Rainsbury, E. A., Bradbury, M., \& Cahan, S. F. (2009). The impact of audit committee quality on financial reporting quality and audit fees. Journal of Contemporary Accounting \& Economics, 5 (1), 20-33.

[67] Salloum, C., Azzi, G., \& Gebrayel, E. (2014). Audit committee and financial distress in the middle east context: Evidence of the Lebanese financial institutions. International Strategic Management Reopinion, 2 (1), 39-45.

[68] Salleh, Z., \& Stewart, J. (2012). The role of the audit committee in resolving auditor-client disagreements: a Malaysian study. Accounting, Auditing \& Accountability Journal, 25 (8), 1340-1372.

[69] Alzoubi, E. S. S. (2018). Audit quality, debt financing, and earnings management: Evidence from Jordan. Journal of International Accounting, Auditing and Taxation, 30, 69-84.

[70] Alabdullah, T. T. Y., Yahya, S., \& Ramayah, T. (2014). Corporate governance mechanisms and Jordanian companies' financial performance. Asian Social Science, 10 (22), 247.

[71] Fakhfakh, H., \& Fakhfakh, M. (2010). The impact of Revised ISA 700: an international empirical comparison. International Journal of Accounting, Auditing and Performance Evaluation, $6(2-3), 274-326$.

[72] Gold, A., Gronewold, U., \& Pott, C. (2012). The ISA 700 auditor's report and the audit expectation gap-do explanations matter?. International Journal of Auditing, 16 (3), 286-307.

[73] Midi, H., Sarkar, S. K., \& Rana, S. (2010). Collinearity diagnostics of binary logistic regression model. Journal of Interdisciplinary Mathematics, 13 (3), 253-267.

[74] Baxter, P., \& Cotter, J. (2009). Audit committees and earnings quality. Accounting \& Finance, 49 (2), 267-290.

[75] Tsipouridou, M., \& Spathis, C. (2014). Audit opinion and earnings management: Evidence from Greece. In Accounting Forum (Vol. 38, No. 1, pp. 38-54). Elsevier.

[76] Firth, M., Fung, P. M., \& Rui, O. M. (2007). Ownership, twotier board structure, and the informativeness of earningsEvidence from China. Journal of accounting and public policy, 26 (4), 463-496.

[77] Ishak, S., Yusof, M., \& Atef, M. (2013). The formation of separate risk management committee and the effect on modified audit report. Malaysian Management Journal (MMJ), 17, 43-58.

[78] Chen, F., Peng, S., Xue, S., Yang, Z., \& Ye, F. (2016). Do Audit Clients Successfully Engage in Opinion Shopping? Partner Level Evidence. Journal of Accounting Research, 54 (1), 79-112.

[79] Fang, J., Lobo, G. J., Zhang, Y., \& Zhao, Y. (2018). Auditing related party transactions: evidence from audit opinions and restatements. Auditing: A Journal of Practice \& Theory, 37 (2), 73-106 